\author{
Kazimierz MROZOWICZ ${ }^{1}$ \\ Piotr HALEMBA ${ }^{2}$ \\ Dariusz KŁAK ${ }^{3}$
}

\title{
ORGANISATIONAL CLIMATE AS AN IMAGE OF ORGANISATIONAL CULTURE (IN THE LIGHT OF RESEARCH ON POLISH ORGANISATIONS)
}

The article is an attempt to scientifically represent the specificity of organisational culture of Polish companies, but also the differences within the scope of developing the attributes of cultures of state and market organisations, with the use of empirical evaluation of attitudes of their members in relation to the organisational climate prevailing in them. Organisational climate is understood here as visualisation (demonstration, materialisation) of "subconscious", profound and hidden from the organisation's environment (but also in a way from itself) values, norms and artefacts. The phenomenon of organisational climate is so interesting from a scientific point of view, that it may be subject to empirical verification in the workers' attitudes due to its volitional (the members of an organisation have a will), cognitive (the members have an intellectual ability), emotional (the members are willing) and psychomotor (the members have technical competence) nature. It is also relatively easily attainable source of data, which raises its practical value and lowers the cost of research. Organisational climate is - according to the authors' analytical convention - a logical, intuitive, generalised and extrapolated form of perceiving and expression by the community (an individual, group, and team) of an organisation - in the form of feelings, opinions as well as the behaviour of its participants - of the culture which characterises it. The purpose of the research was thus a diacritical analysis of organisational climate of bureaucracy and adhocracy (according to the authors, organisational climate is a synthetic and integral equivalent of organisational culture, considered synonymously as part of the adopted paradigm), developing in Polish organisations.

Keywords: organisational climate, human capital, organisational culture

\section{INTRODUCTION}

Organisational climate is understood here as visualisation (demonstration, materialisation) of ,subconscious", profound and hidden from the organisation's environment (but also in a way from itself) values, norms and artefacts. It needs to be emphasised strongly that they are not realised, are difficult to formulate and thus comprehend judiciously or at the same time have practical applications in the organisation's operational departments. This phenomenon affects all levels of management as well as its various techniques.

Analysis of climate shortens decision making processes, thus reducing the costs connected with long-lasting, expensive and difficult to evaluate process of examining organi-

\footnotetext{
${ }^{1}$ PhD Kazimierz Mrozowicz, The Jerzy Kukuczka Academy of Physical Education in Katowice, 40-065 Katowice, Mikołowska 72A Street, (32) 207-53-24, k.mrozowicz@awf.katowice.pl (corresponding author).

${ }^{2} \mathrm{PhD}$ Piotr Halemba, The Jerzy Kukuczka Academy of Physical Education in Katowice, 40-065 Katowice, Mikołowska 72A Street, (32) 207-53-24, p.halemba@awf.katowice.pl

${ }^{3}$ Dr Dariusz Kłak, Państwowa Wyższa Szkoła Techniczno-Ekonomiczna im. bł. ks. B. Markiewicza, Instytut Ekonomii i Zarządzania, 37-500 Jarosław, ul. Czarnieckiego 16, (16) 621-02-04, dariusz.klak@pwste.edu.pl
} 
sational culture. On the basis of such a formulated implicite assumption, a hypothesis on theoretical, pragmatical as well as economic methods of this competitiveness compared with methods used in science, has been suggested.

The phenomenon of organisational climate is so interesting from a scientific point of view, that it may be subject to empirical verification in the workers' attitudes due to its volitional (the members of an organisation have a will), cognitive (the members have an intellectual ability), emotional (the members are willing) and psychomotor (the members have technical competence) nature. It is also relatively easily attainable source of data, which raises its practical value and lowers the cost of research. It seems equally handy in praxeological respect, as opposed to laborious and long-lasting analytical procedure in diagnosing organisational culture, which was suggested by Cameron and Quinn ${ }^{4}$.

The process of studying organisational culture on the basis of the implicite inference (inference based on the assessment of organisational climate) is subject to remarkable reduction, thus giving a chance to increase the effectiveness of decision making within the line of managers in both tactical and operational management. The authors' research concept, defined in this article, ought to be understood as an alternative analysis method of psychosocial determinants of an organisation's activity.

\section{CULTURE AND ORGANISATIONAL CLIMATE}

In the Anglo-Saxon theory, organisational culture was commonly described as: ,a model of values, norms, beliefs, attitudes and assumptions, which do not have to be formalised, but which shape human behaviour and ways of realising tasks" ". Organisational culture is: ,commonly accepted (in an organisation, authors' note) beliefs, attitudes and values existing in an organisation", which also ,helps to eliminate uncertainty, providing all members of an organisation with one system of interpretation, creates social order through clear definition of what is expected from people, guarantees continuity which lies in next generations of members holding the same basic values and following the same rules, establishes group identity and joint commitment by forming bonds and also facilitates creating the vision of the future" ${ }^{\text {"7 }}$. Popularly, it takes the form of a four-dimensional model $^{8}$.

Human capital reflects the role of intellectual resources of an organisation, that is attitudes, values held by them, motivation, knowledge, predispositions, abilities as well as work skills. It is a combination of intelligence, capability and competence, which constitute a distinct character of an organisation. The human element is such that it is able to learn, change, introduce innovations, act creatively, and that will guarantee long-lasting existence of an organisation when well motivated. Unlike the other resources it does not

\footnotetext{
${ }^{4}$ K.S. Cameron, R.E., Quinn Kultura organizacyjna - diagnoza i zmiana. Model wartości konkurujących, Oficyna Ekonomiczna, Kraków 2003.

${ }^{5}$ M. Armstrong, Zarządzanie zasobami ludzkimi, Oficyna Ekonomiczna, Kraków 2005, p. 248.

${ }^{6}$ A. Furnham, B. Gunter, Corporate Assessment, Routledge, London 1993, p. 34.

${ }^{7}$ K.S. Cameron, R.E., Quinn, op. cit.

${ }^{8}$ Compare R. Harrison, Understanding your organizations character, Harvard Business Review, 1972, 5, pp.119-128; C. Handy, Understanding Organizations, Penguin, Harmondsworth 1981, E.H. Schein, Organization Culture and Leadership, Jossey-Bass, New York 1985; A. Williams, P. Dobson, M. Walters, Changing Culture: New organizational approaches, IPA, London 1989.
} 
belong to the organization ${ }^{9}$. Human capital is the most important component of intellectual capital, which consists of knowledge, acquired in the organisation and spread throughout it, and belongs to immaterial resources, which along with the material resources (money and fixed assets) create a market or total value of the organisation ${ }^{10}$.

Organisational climate is: ,, a relatively permanent set of observations of organisation members, relating to the features and quality of organisational culture" ${ }^{11}$. Organisational culture reaches a deep and partly unenlightened organisational structure which determines its fundamental principles and rules, whereas organizational climate shows currently perceived and realised aspects of an organisation's activity. In light of the above it may be said that organizational climate is a catalogue of current observations, views and beliefs of members of an organisation regarding norms, values, principles, as well as rules of conduct which develop in it, but also an expression of opinions about the performed role in developing an organisation, thus influencing the nature and shade of interpersonal relations and general atmosphere at work, which is expressed in the actions of individuals and teams.

\section{THEORETICAL INSPIRATION FOR THE RESEARCH}

In the authors' study of organisational climate, whose results are included in the presented article, a bit forgotten concept of George Litwin and Robert Stringer ${ }^{12}$ has provided a source of inspiration. The aforementioned authors in their monograph entitled: „,Motivation and Organisational Climate”, presented a model questionnaire used in empirical measurement of organisational climate ${ }^{13}$, in which they included eight categories of variables, characterising a particular organisation, and among them dimensions as follows ${ }^{14}$ :

- Structure - understood as observations on barriers and autonomy of action, but also a degree of formalising and hierarchisation of organisational processes etc.

- Responsibility - perceiving oneself as treated with respect and trust in situations of delegating powers to do important tasks etc.

- Risk - perceiving organisational activities as dangerous and risky, in which the emphasis is on taking calculated risk, as well as preference for safe behaviour, etc.

- Warmth - existence of informal and friendly interpersonal relations, inducting the atmosphere of teamwork, developing and supporting decentralised bonds etc.

${ }^{9}$ D. Kłak, Organizational dimension of management of human capital selection process, Pragmata tes Oikonomias - VIII, Wydawnictwo Akademii im. Jana Długosza w Częstochowie, Częstochowa 2014.

${ }^{10}$ B. Kłak, D. Kłak, Kapitat intelektualny w ksztattowaniu wartości przedsiębiorstwa, [w:] Galata S. (red.), Uwarunkowania strategii zarządzania nowoczesnymi organizacjami, Wydawnictwo Naukowo - Dydaktyczne PWSZ w Jarosławiu, Jarosław 2008, p. 94.

${ }^{11}$ W.L. French, F.E. Kast, J.E. Rosenzweig, Understanding Human Behaviour in Organizations, Harper \& Row, New York 1985, p. 82.

${ }^{12}$ G.H. Litwin, R.A. Stringer, Motivation and Organizational Climate, Harvard University Press, Boston 1968.

${ }^{13}$ (Original name of the questionnaire: ,Organizational Climate Questionnaire” - LSOCQ)

${ }^{14}$ Giving a feature the form of dimension denotes that its structure is founded on a vector with average intensity of the analysed phenomenon, whereas in both research and assessment one acknowledges the fact of potential occurrence of extremes of intensity (characterises entirely or does not characterise at all). In this case, the subject features function as attributes, based on internalised as a result of organisational socialisation norms, encoded in the catalogue of organisational roles and regulations (scripts) on fulfilling them. 
- Support - noticeable help from management, superiors and co-workers, emphasis on cooperation, kindness, etc.

- Standards - existence of standardised rules and criteria of control, grasped by human resources meaning of aims and standards of actions, emphasis on achieving personal and team goals, etc.

- Conflict - the feeling that the board, superiors and co-workers avoid settlements and conceal problems by ignoring or underestimating and reducing their real meaning (repression) etc.

- Identity - the sense of belonging to the organisation, team, group, loyalty towards other participants, perceiving oneself as a valuable resource, experiencing affiliation as well as respect and recognition from others, etc.

In all types of organisations, effective and skilfull managers and specialists, whether they hold the post of state enterprise directors or manage market companies, whether are administrators in civil service or consultants within organisations, need to acquire an ability, or even proficiency in the art - as referred to by Gareth Morgan ${ }^{15}$ - ,of deciphering situations in which they attempt to manage something or organise something". This skill, deriving from inborn predispositions and talents, most frequently develops as a natural process as part of routine activities and actions, which appears to be an intuitive process, and decisions made within this process were taken subconsciously. Besides, often without rational justification, we ascribe almost supernatural powers to the most effective managers, believing that people able to solve difficult problems bring this gift with themselves into the world, moreover, they are in possession of some sort of magical power, enabling them to understand and transform situations they face.

The authors of this study, however, take the opposing view, claiming that the ability to perceive, identify and evaluate the organisation along with its surroundings in the light of their mutual interactions and the context of this feedback, is a result of arduously acquired thorough knowledge, but also systematically gained valuable experience, obtained during social processes by the optimally configured personality of the decision-maker. In a model in which the decision-maker plays fundamental yet not the only role, other people and values on which they build groups, teams and organisations, formed on the basis of the established norms, get substantial meaning. It is worth looking at and getting to know their views in order to gain another piece of interdisciplinary knowledge, which may turn out useful in the process of managing the organisation, still remembering that social construction of reality is a categorical and universal conditioning. Regardless of what one thinks about the theory of Karl Weick, it cannot be definitely contested, and therefore a compromise ought to be reached. An optimal solution to the emerging dilemma: ,whether to believe in observations as a base for solid knowledge about social and economic reality, or not to believe in them", becomes understanding and assessing cognitive processes of people who form organisations and perform (within their formal-legal frameworks) routine roles and occupational functions, in the face of which they adopt specific attitudes expressed in the voiced opinions and preferred activities or behaviour styles.

In light of the above-mentioned deliberations, a few research questions have been raised, namely:

${ }^{15}$ G. Morgan, Obrazy organizacji, PWN, Warszawa 2005, p. 9. 
- What are the characteristics of a phenomenon which makes the members of a particular organisation see it in an identical way, interpret processes existing in it in a consistent way and feel the overwhelming necessity to act in accordance with the created within the organisation axio-normative construction?

- Are there any determinants of developing organisational behaviour and what characterises their relationship with ethos and atmosphere prevailing in the whole organisation?

- Are there any theoretical and logical premises to imply about such subjects as organisational culture on the basis of the research on workers' attitudes? If so, can the climate prevailing in it be regarded as a designation of organisational culture, expressed in the form of beliefs, emotional reactions and behaviour of people who work within its structures?

Do types of organisations attract individuals of similar and consistent attitudes, or is it coherence and cohesion of their conduct which lead to the development and maturation of uniform organisational culture? Are various types of organisations characterised by specific types of organisational cultures? Can adhocracy and bureaucracy be regarded as an example of antagonised organisational cultures and what characterises the attitudes of their members?

\section{METHODOLOGY OF AUTHORS' RESEARCH}

In order to provide answers to the raised research questions, a nomothetic approach has been used, in the light of which no efforts have been spared to show the characteristics of organisational cultures of adhocracy and bureaucracy in attitudes towards organisational climate.

\subsection{The logic of research model and research group}

Taking the considered research issues into account, a methodological convention in the area of social sciences and studies on management has been used. The statistical survey, carried out as part of it, was conducted at the turn of the year 2009. The sample was taken among the general population of state-owned and municipal enterprises and civil service workers as well as the workers of private and market enterprises of the Subcarpathian Voivodship. In the used empirical model, bureaucracy became the designation of state organisations, whereas adhocracy demonstrates processes of market organisations and reflects the traits of its participants. In order to compare the characterisation of attitude of the members of adhocracy and bureaucracy with organisational climate prevailing in their organisations, the sample was divided into two homogeneous fractions. The research group (group A) consisted of 120 members of adhocracy, whereas the control group (group B) consisted of 120 members of bureaucracy. Collection of the sample as well as its division were of controlled nature, since it has been an aim to achieve such a state in which the influence of uncontrolled variables on variables under observation would be standardised as far as possible in both groups. Because of the representative sample size, analysis of the differences within the scope of characterisation of the analysed variables was based on the structure of percentage distribution with the reservation that the noticed differences could not be assessed in terms of statistical significance. 


\subsection{Research tool and hypotheses}

Comparative analysis, referred to as diacritical, for its purpose is to show and describe differences in the area of the observed variables - features (categories) of organisational climate, has been carried out by way of the authors' questionnaire form entitled Inwentarz Dobrej Roboty (An Inventory of Good Work) $(K M I D R)^{16}$. It consists of five dimensions, intended for measuring and assessing the qualities of factors which in total create the syndrome of organisational climate. The scale which evaluates the nature of organisational culture is formed by five sets of questions of diverse diagnostic structure, adjusted to the content of the analysed dependent variables. Each of the eight categories of the aforementioned Litwin\&Stringer's model corresponded with a certain catalogue of survey questions, included in the KMIDR tool.

In connection with the raised research questions, the following hypotheses have been discussed:

- it is assumed that organisational culture, manifested in organisational climate, is in fact visible in the attitudes of organisation members,

- it is assumed that in terms of attitudes towards organisational climate, differences of views between the members of adhocracy and bureaucracy will appear.

\section{ORGANISATIONAL CLIMATE IN THE LIGHT OF EMPIRICAL RESEARCH}

As a result of the conducted research a few regularities have been noticed in the area of developing subjects' attitudes from research group (group A) and control group (group B).

\subsection{Motivation factors in the spectrum of organisational climate}

Obtained research results show that the main motivation factor differentiating work satisfaction in groups A and B is the level of pay, which is more often described as satisfactory in the opinion of state administration workers (referred to as bureaucracy) than in the group of market organisation members. It confirms the popular opinion that working in the public sector guarantees financial stability and secures basic existential and social needs. There are no clear differences in opinions of the two groups when it comes to evaluation of the level of kindness in human relations in a team, possibilities of further career development and the possibility to make decisions about the performed work (see Fig. $1 \mathrm{AB}$, below).

\footnotetext{
16 The questionnaire is found in the collections of research tools of the Institute of Physical Culture and Sport Management at the Academy of Physical Education in Katowice and is an authors' paper, intended for scientific research.
} 


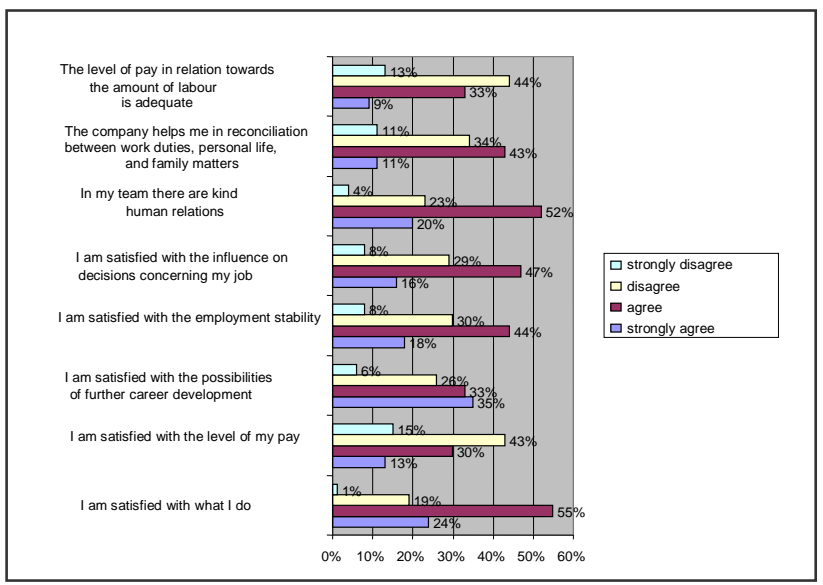

Fig. 1A. Distribution of attitudes towards motivation factors in group A

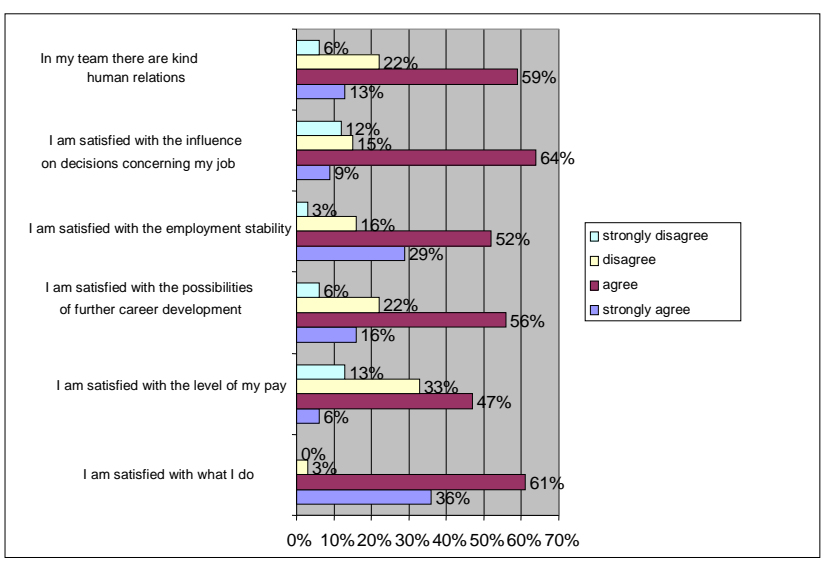

Fig. 1B. Distribution of attitudes towards motivation factors in group B

In relation to the results of the whole research a few alarming conclusions might be drawn, namely:

- every third subject believes that in his/her team there are hostile human relations and problems with creating an atmosphere of shared kindness,

- a considerable percentage of the subjects believe that they do not have any decision making influence on their work,

- in case of group A, almost $60 \%$ of subjects is dissatisfied with the level of received pay, every fifth subject from a market company performs his/her work out of necessity.

\subsection{Management in the spectrum of an organisational climate}

The analysis of attitudes of members of the two groups A and B towards the activities 
of personnel managers demonstrated in the form of: listening to employees' remarks and opinions about working conditions, taking care of employees' further career development, objectivity and rationality in the process of promotion, the use of financial methods of motivation and encouraging work effectiveness, as well as systematically informing its personnel about organisation's plans of development, has not shown any evident differences (please see Fig. 2AB). However, it should be emphasised that the above-mentioned factors of organisational climate have been evaluated in an ambivalent way, not to say negative, regardless of the organisation type in which they are used as a managing instrument.

In the light of the obtained results it has been anxiously discovered that:

- every second subject believes that his/her organisation does not take into consideration one's opinions and ideas, almost $30 \%$ of the subjects is of the opinion that their career development is not being taken care of,

- $\quad$ promotion, in the opinion of almost half of the interviewed, is still given due to favouritism and nepotism, ways of pay, according to $30 \%$ of subjects, do not encourage work efficiency.

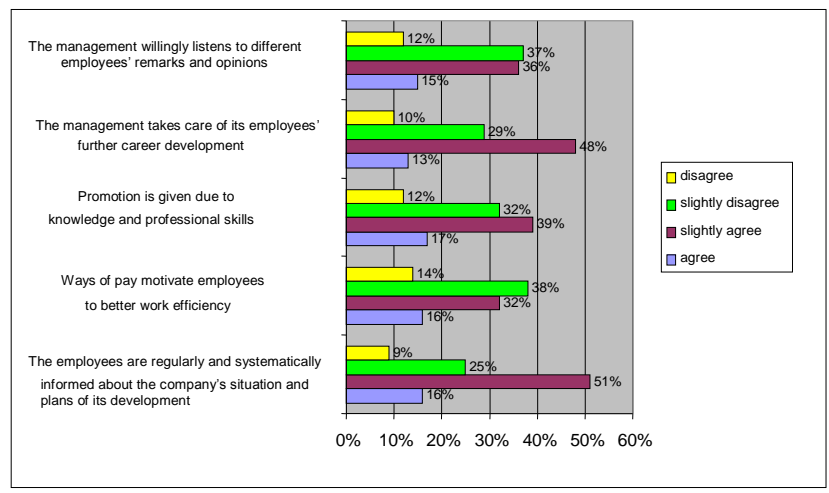

Fig. 2A. Distribution of attitudes towards personnel managers and supervisors in group A

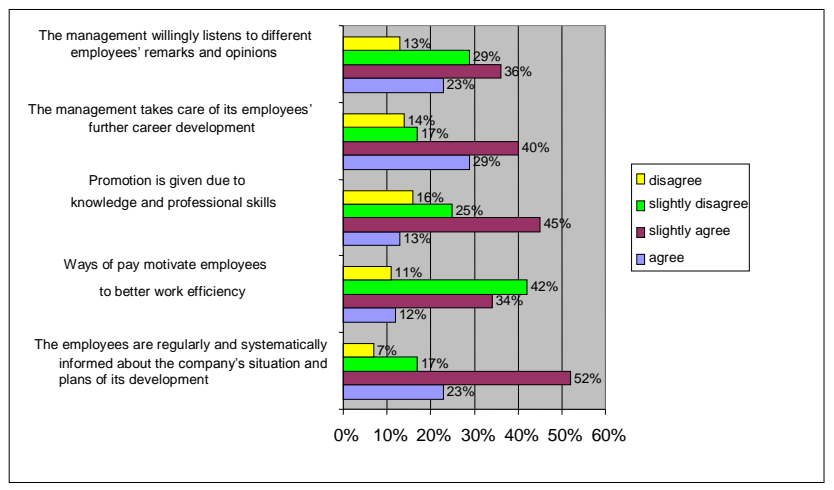

Fig. 2B. Distribution of attitudes towards personnel managers and supervisors in group B 


\subsection{Information in the spectrum of organisational climate}

The analysis of opinions about the methods of information management in the organisation has shown that formal channels of information transfer are used more often in bureaucracy (from management's announcements, from the supervisor, from team representative) than in market organisations where, in turn, informal oral information transfer is more predominant (Fig. 3AB, below). In both types of organisations traditional technologies and styles of communication play a predominant role and ,hierarchical band" of official channels comes to the fore.

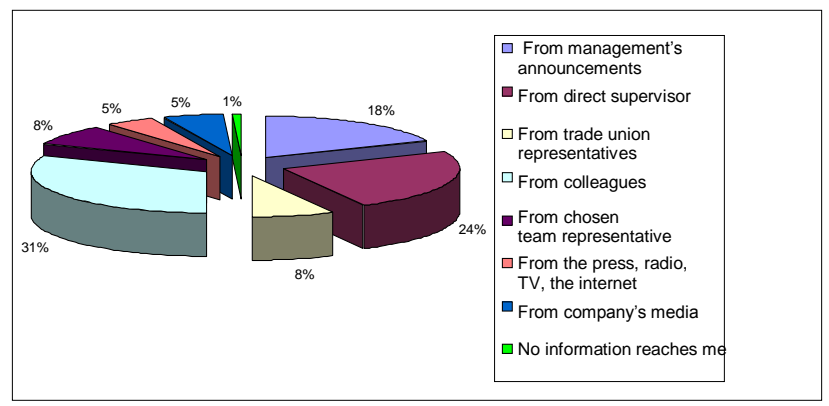

Fig. 3A. Distribution of attitudes towards information management in organisation in group A

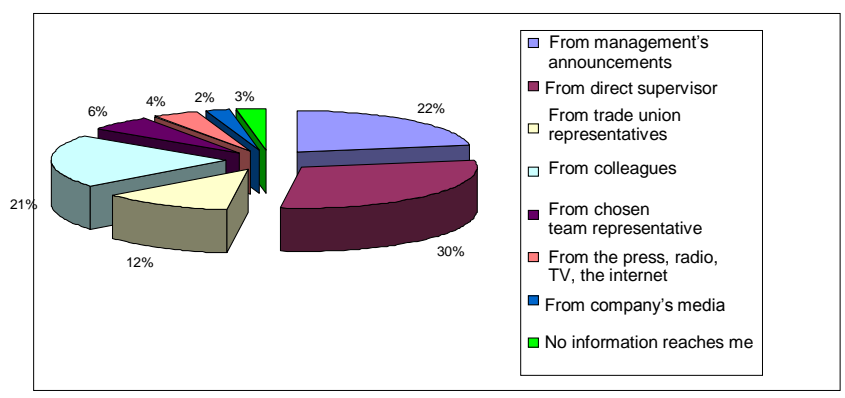

Fig. 3B. Distribution of attitudes towards information management in organisation in group B

\subsection{Stressogenic factors in the spectrum of organisational climate}

The analysis Factors which cause stress in adhocracies - enumerated in a descending order of importance - are: I - overworking, overstrain (16\%), II - burdensome working conditions (13\%), III - favouritism as far as differences in pay and giving promotion are concerned $(10 \%)$ and also III - unexpected changes and sudden turns, changes of decision, IV - poor work organisation $(9 \%), \mathrm{V}$ - low self-esteem in the eyes of supervisors, VI - supervisors' subjective evaluation of work (7\%), VI - the lack of possibility to openly express ideas, VI - the lack of support from the team representative (7\%) as well as VII 
- the lack of support in problematic situations (6\%) (see Fig. 4AB, below).

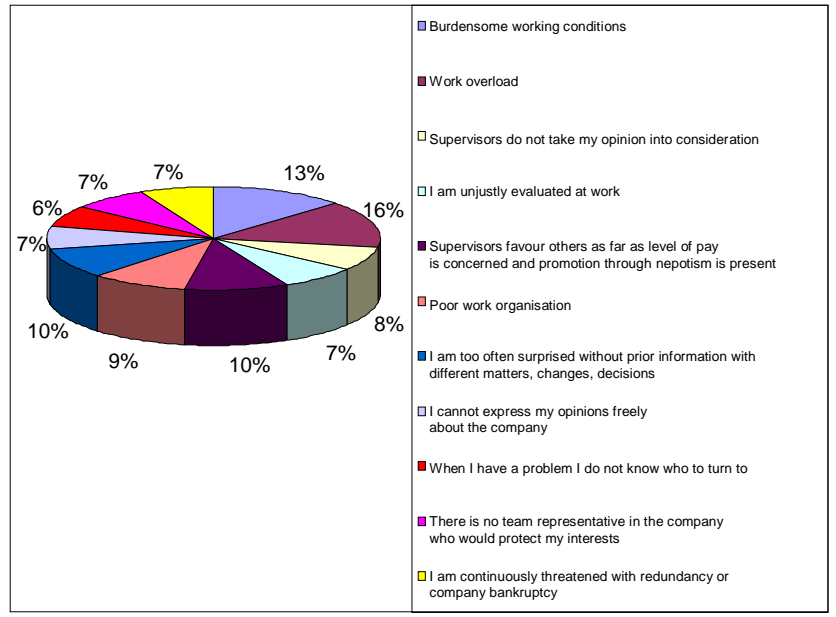

Fig. 4A. Distribution of attitudes towards stressogenic factors in organisation in group A

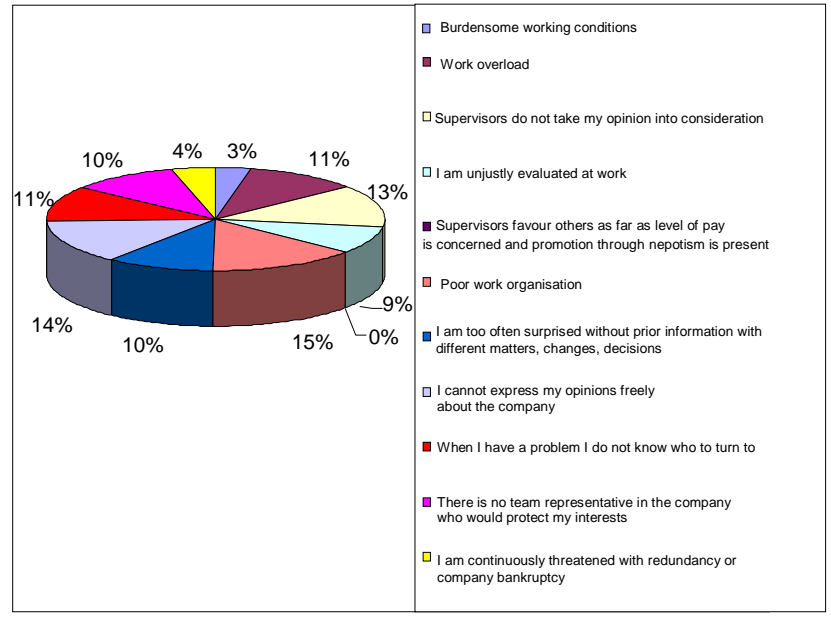

Fig. 4B. Distribution of attitudes towards stressogenic factors in organisation in group B

In case of the analysis of attitudes of employees from public companies, the leading stressogenic factor (importance I) is poor work organisation (15\%), then the following (importance III) is the lack of ability to express ideas freely $(14 \%)$ and supervisors not taking into account their subordinates' opinions (importance III, 13\%). Whereas on the next consecutive positions are: IV - the lack of trusted supervisor or co-worker (11\%) and work overload (11\%), V - unexpected changes and surprising turns $(10 \%)$ as well as lack of representative of employees' interests (10\%), VI - unjust evaluation (9\%), and finally the least important: the lack of appreciation in the supervisor's eyes (VII, 4\%) and bur- 
densome working conditions (VIII, 3\%).

The oddity of the analysed distribution of attitudes is demonstrated in the fact that in bureaucracies, there is a complete lack of favouritism and nepotism as far as giving promotions and differences in pay are concerned, which is surprising enough and puts into question not only the common belief (that nepotism is widespread in public sector) but even the theories describing social occurrences shown in broad subject literature. What is also surprising is the fact that subjects from group B positively evaluate their supervisors in terms of taking into account their employees' opinions (compare Fig. 4AB, above).

It has been noticed that the most important difference in developing attitudes and opinions of the members of bureaucracy and adhocracy is based on the fact that the first group (bureaucracy) state that everyday working conditions are not burdensome for them, while the company employees claim the complete opposite - that they work in difficult conditions under time constraints, physical obstructions and are overworked. It should be mentioned that this kind of situation leads to, according to Tadeusz Tomaszewski's theory (theory of action), overstrain and psychophysical exhaustion, whose results can be damaging and very often irreversible (job burnout syndrome) for employee's work efficiency.

\subsection{Direct supervisor in the spectrum of organisational climate}

The analysis Over half of the subjects from group A believe that their supervisor is not able to infect them with enthusiasm and what makes the matter worse, in the eyes of their subordinates, he/she is rather a poor specialist (see Fig. 5AB).

Most of the time he/she does not take into consideration one's subordinates' opinions and makes decisions regardless of their arguments, dividing unjustly bonuses and rewards. In his/her actions a supervisor is goal-oriented, authoritative and uncompromising in goal pursuit, ignoring one's subordinates' opinions (almost 75\%).

Apart from the above-mentioned pejorative features, in the opinion of subjects from group A: a supervisor is good at work organisation (c. 65\%) and resolving problems within the team $(58 \%)$, offering at the same time clear and sufficient information $(71 \%)$ and engaging employees (about 65\%).

In relation to attitudes of group B members, the research results are slightly different, in particular in terms of the evaluation of supervisor's professionalism whose competences not only leave no doubts but on the contrary distinguish him/her as a top class specialist (c. $70 \%)$.

It should also be emphasised that in majority, the evaluations of management skills of direct supervisors in group B are positive. In most cases, the supervisor justly divides bonuses (61\%) and takes into account employees' opinions (c.55\%), which differentiates him/her from the supervisor from group A.

In light of the attitudes of all the subjects, among the characteristic features of management of the direct supervisor's, the same features are mentioned, being referents of autocratic style of management whose accelerator is the realisation of organisational goals.

It should be added that the direct supervisor in the opinion of bureaucracy and adhocracy workers has been, nevertheless, much higher noted than the organisation's management (see Fig. 2AB). 


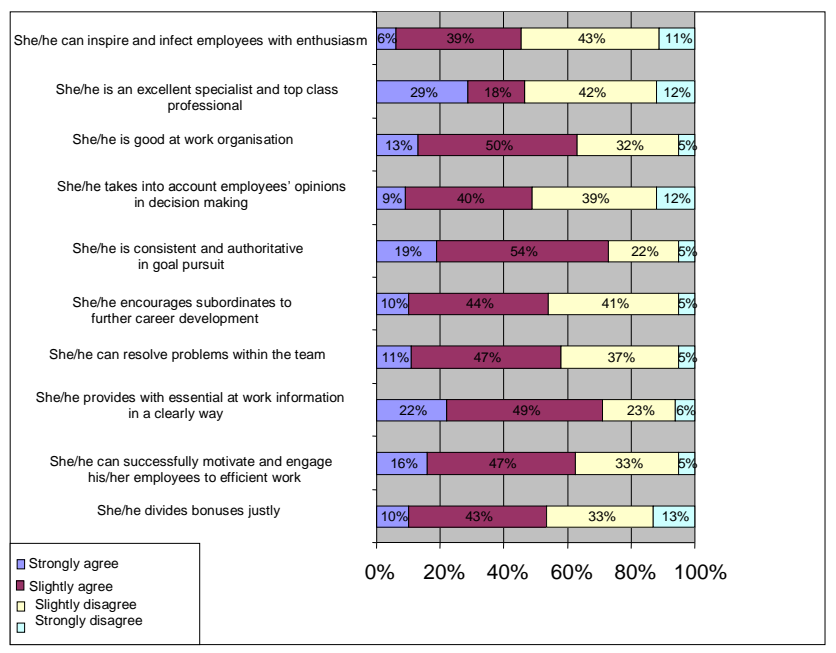

Fig. 5A. Distribution of attitudes towards the style of supervisor's management in group A

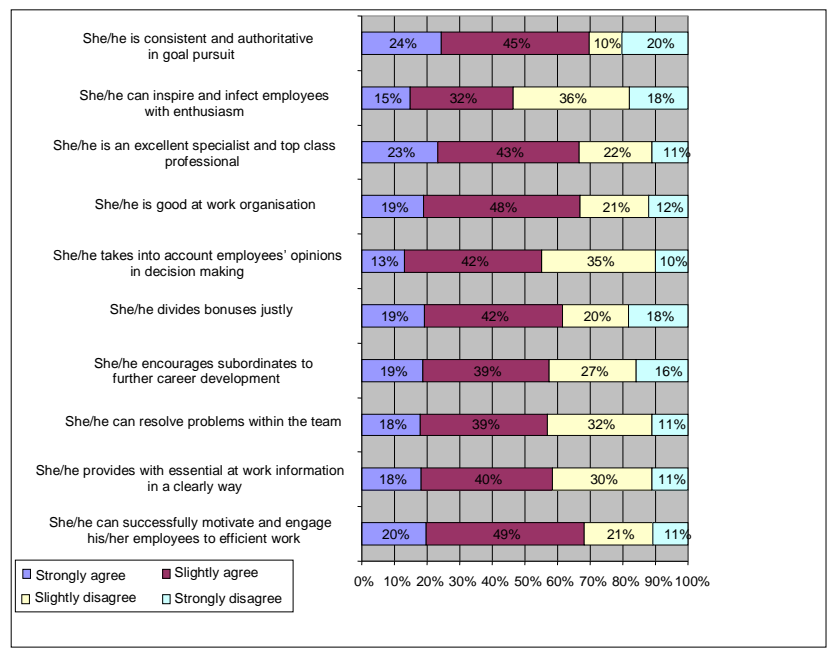

Fig. 5B. Distribution of attitudes towards the style of supervisor's management in group B

\subsection{Decision making rights in the spectrum of organisation climate}

One of the questions asked to the workers of both public and market companies, was ,which type of situation would satisfy you the most as a team member?". It was a multiple choice type of question and subjects could choose from seven options. As a result of the conducted research the following distribution of answers has been obtained in both groups. Twice as often adhocracy workers (c.20\%), in comparison to their colleagues from bureaucracy $(10 \%)$, have pointed as satisfactory the situation of limited influence on 
their supervisor's decision who, although consults the decision with his/her team, also accepts any consequences herself/himself.

Reversed situation can be noticed when dealing with a situation in which the supervisor arbitrarily makes decisions informing her/his subordinates about them and requiring unquestioning obedience. Situation of this type has been satisfactory twice as often to the members of group B, which confirms the ,,internalised hierarchy syndrome” and ,learned helplessness"- characterising bureaucracy.

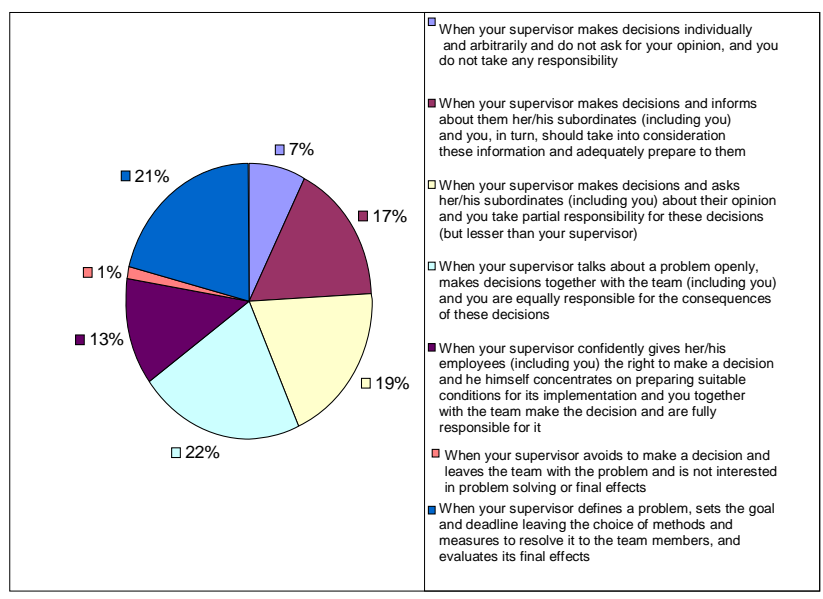

Fig. 6A. Distribution of attitudes towards participation in the decision making processes in group A

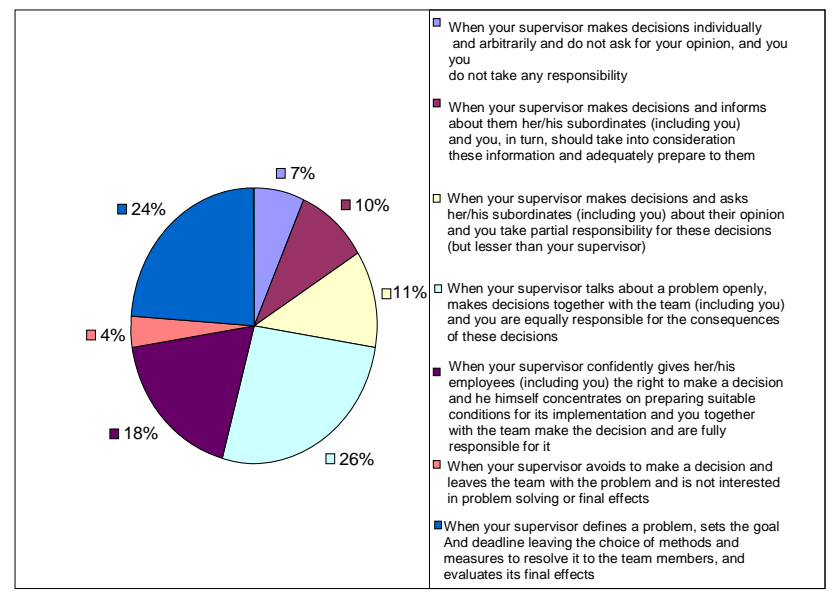

Fig. 6B. Distribution of attitudes towards participation in the decision making processes in group B 
K. Mrozowicz, P. Halemba, D. Kłak

From the point of view of the sample from bureaucracy and adhocracy members, the following have been regarded as the most satisfactory decision making situations: codecision and joint decision making responsibility (every fifth subject) and total decision making responsibility (preferred by every fifth interviewed), therefore, it may be concluded that almost $70 \%$ of the analysed members of organisational cultures prefer conditions in which they would influence organisational decision making without fearing the consequences and taking responsibility for them.

\subsection{Loyalty in the spectrum of organisational climate}

The research results demonstrate that predominant factor in making a decision to leave a company and start working for a rival company is the level of pay. The age of the subjects, their family situation, education background and time left to retirement etc. have been omitted. These data could, in some way, change the obtained results, nevertheless, observed attitudes are not at variance with documented thesis about motivation and existential influence of salary. Majority of the interviewed from both groups A and B (over $60 \%$ ) would change their jobs, if the rate of pay rose considerably. Group B members $(8 \%)$ more rarely would be inclined to do so, if they were offered lower basic salaries and performance-based bonuses, than subjects from group A (12\%). Curiously, when offering subjects from group B to raise their salaries by half (over 20\%) and doubling it (40\%), an increased interest in rival companies is noticed. Bureaucratic loyalty has, therefore, a high price but is hardly realistic. In case of both groups of subjects there is a certain, stable - in terms of loyalty towards the company - group of workers, which in case of group $\mathrm{B}$ is only insignificantly bigger. Taking into consideration the previous research results, which show that bureaucracy workers are more content with the work environment as well as working conditions and rates of pay, the loyalty level as far as they are concerned is surprisingly low.

\subsection{Employment stability in the spectrum of organisational climate}

In the table shown below, which is taken from one of the scales of KMIDR questionnaire, a simulation of certain work situation is included and subjects from groups A and B were asked to choose alternative answers (Table 1, below). The content of the task reads as follows: ,let's assume that you are currently looking for a job. You have received a few job offers. Please choose one answer from each of the 6 pairs of job offers given (please mark your answers by putting , $x$ ” in the box, each time marking only one box)".

Table 1. Alternative answers in the set of multiple choice questions in the KMIDR questionnaire

\begin{tabular}{|c|l|c|}
\hline No. & \multicolumn{1}{|c|}{ Content of the offer } & X \\
\hline 1. & Genesis Inc. offers competitive rates of pay but does not guarantee employment & \\
A. & stability & \\
\hline 1. & Museo Rosenbach Company offers rather low pay but guarantees long term & \\
B. & employment stability & \\
\hline 2. & Banco del Mutuo offers competitive pay but do not offer any training possibili- & \\
A. & ties & \\
\hline 2. & Premiata Forneria offers rather low pay but offers a lot of training opportunities & \\
B. & \\
\hline
\end{tabular}




\begin{tabular}{|c|l|l||}
\hline 3. & $\begin{array}{l}\text { Yes Inc. offers attractive pay but at the same time employees do not influence } \\
\text { decision making concerning their work (work organisation, distribution of bo- }\end{array}$ & \\
nuses, working conditions) & $\begin{array}{l}\text { Jethro Tull Inc. offers rather low pay but at the same time employees influence } \\
\text { decision making concerning their work (work organisation, distribution of bo- } \\
\text { nuses, working conditions) }\end{array}$ & \\
\hline B. & $\begin{array}{l}\text { Nazareth Corporation guarantees long term employment stability but does not } \\
\text { offer any training }\end{array}$ & \\
\hline A. & $\begin{array}{l}\text { Carravan Inc. does not offer long term employment stability but offers, on the } \\
\text { B. }\end{array}$ other hand, a lot of training opportunities & \\
\hline 5. & $\begin{array}{l}\text { Omega LLC. guarantees long term employment stability but simultaneously } \\
\text { employees do not influence decision making concerning their work (work organ- }\end{array}$ & \\
A. & isation, distribution of bonuses, working conditions) & \\
\hline 5. & $\begin{array}{l}\text { Rush LLC does not guarantee long term employment stability but employees } \\
\text { influence decision making concerning their work (work organisation, distribution }\end{array}$ & \\
B. & of bonuses, working conditions) & \\
\hline 6. & $\begin{array}{l}\text { Pink Floyd Inc. offers its employees a lot of training opportunities but simultane- } \\
\text { ously employees do not influence decision making concerning their work (work }\end{array}$ & \\
A. & organisation, distribution of bonuses, working conditions) & \\
\hline 6. & $\begin{array}{l}\text { Led Zeppelin Inc. does not offer its employees any training but employees, on } \\
\text { the other hand, influence decision making concerning their work (work organisa- }\end{array}$ & \\
B. & tion, distribution of bonuses, working conditions) & \\
\hline
\end{tabular}

In the light of the obtained findings, it appears that the members of group A most willingly would choose the following job offers: „Banco del Mutuo offers a very competitive rate of pay but does not offer any training possibilities” (c.70\%) and „Museo Resenbach Company offers rather low pay but it guarantees, on the other hand, employment stability” (53\%) and ,,Yes Inc. offers attractive pay but at the same time employees do not influence decision making concerning their work (work organisation, distribution of bonuses, working conditions)" (55\%); the remaining alternative offers have been treated with moderate optimism and the attitudes towards them have been distributed evenly. It means that half of the employed in adhocracies appreciate non- financial components of pay and their motivation is based not only on Herzberg's hygiene factors but also encompasses satisfaction factors.

Attitudes of group B members are slightly different; they tend to choose offers by Banco del Mutuo (68\%), Museo Rosenbach (62\%) and Yes Inc. (52\%) more willingly than members of group A. They also highly evaluated another job offer: „Nazareth Corporation guarantees long term employment stability but does not offer any training" (c.70\%) and „Omega LLC guarantees long term employment stability but simultaneously employees do not influence decision making concerning their work (work organisation, distribution of bonuses, working conditions)" (61\%). A diacritical model of attitudes towards financial and non-financial components of pay takes its extreme form in relation to the following job offer: ,,Led Zeppelin Inc. does not offer its employees any training but employees, on the other hand, influence decision making concerning their work (work organisation, distribution of bonuses, working conditions)", which would be interesting to almost all the subjects from group B (c.85\%).

They would ignore, however, the following job offer „Pink Floyd Inc. offers its employees a lot of training opportunities but simultaneously employees do not have any 
influence on decisions concerning their work (work organisation, distribution of bonuses, working conditions)" (71\%). Members of group B working in formal organisations prefer to influence decision-making concerning social factors, bonuses, division of labour, level of pay, significantly neglecting at the same time the need and will for their further professional development. It confirms the existence of the „learned helplessness" syndrome in bureaucracy. Attitudes of this type are reinforced by the present among bureaucracy members mechanisms of social influence with group thinking as well as the truths proclaimed at the front. Tendencies to possess power have also been revealed.

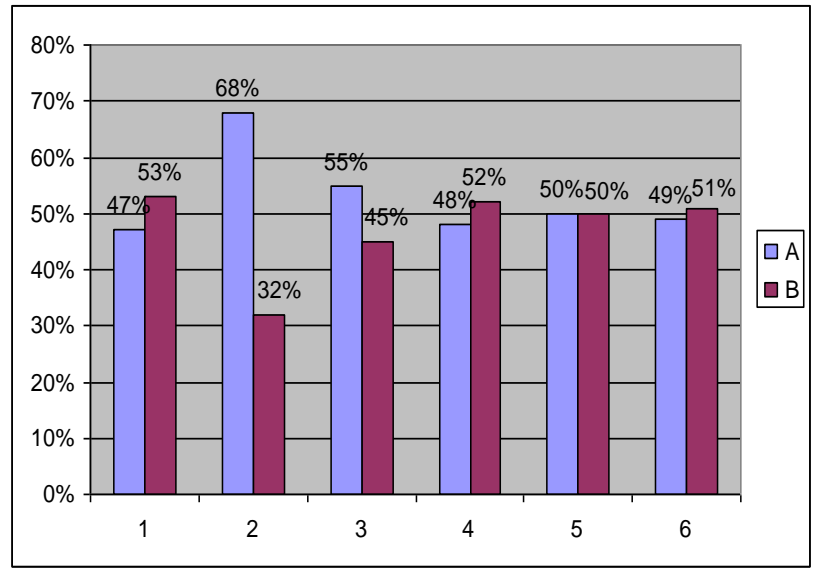

Fig. 7A. Distribution of attitudes towards employment stability and level of pay in group A

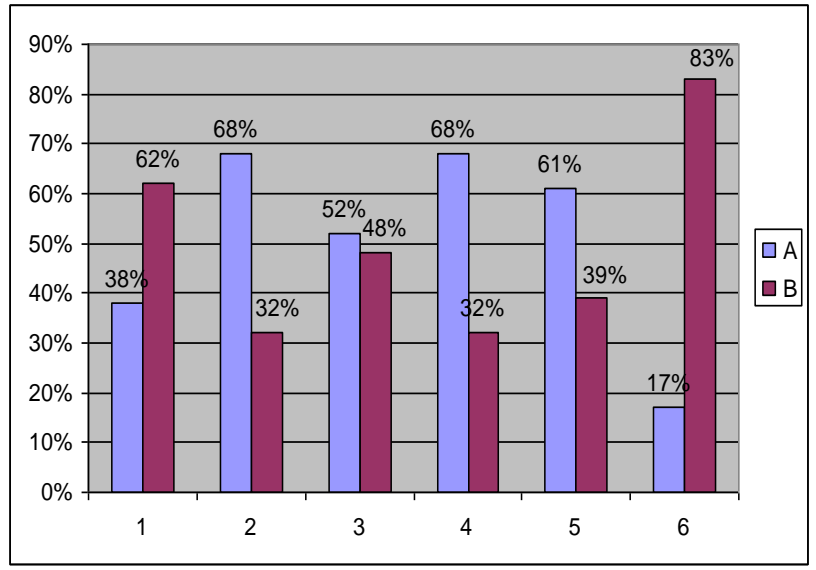

Fig. 7B. Distribution of attitudes towards employment stability and level of pay in group B

\section{Verification of research hypotheses and conclusions}

In light of the conducted research, it has been noted that organisational climate expressed in the form of workers' attitude in a diacritical model of adhocracy and bureau- 
cracy, is characterised by the existence of certain specific views, feelings and behaviours. Description of predominant values, norms and bundles of behaviours is presented by the Diacritical Model of Organisational Climate of Bureaucracy and Adhocracy (see Table 2, below).

Table 2. Diacritical Model of Organisational Climate of Bureaucracy and Adhocracy

\begin{tabular}{|c|c|c|}
\hline $\begin{array}{l}\text { Categories } \\
\text { of organisa- } \\
\text { tional climate } \\
\text { in the concept } \\
\text { of Litwin } \\
\text { \& Stringer } \\
\text { (1966) }\end{array}$ & $\begin{array}{c}\text { Mechanistic organisation } \\
\text { (Dominant features of the climate } \\
\text { of bureaucracy according to the } \\
\text { author's research) }\end{array}$ & $\begin{array}{l}\text { Organic organisation } \\
\text { (Dominant features of the climate } \\
\text { of adhocracy according to the au- } \\
\text { thor's research) }\end{array}$ \\
\hline Structure & $\begin{array}{l}\text { aspiring to power \& the need of } \\
\text { power, need of employment stabil- } \\
\text { ity, recognition of authority, subor- } \\
\text { dination and admiration for one's } \\
\text { supervisor, allocation of decision } \\
\text { rights at higher levels of manage- } \\
\text { ment, autocratic management style, } \\
\text { centralisation, hierarchy of interper- } \\
\text { sonal relationships, distanced \& } \\
\text { hostile human relations, lack of } \\
\text { incentive pay systems, lack of } \\
\text { support, sense of alienation, poor } \\
\text { organisation of work, etc. }\end{array}$ & $\begin{array}{l}\text { need of accomplishments and devel- } \\
\text { opment, financial \& non-financial } \\
\text { motivation, limited influence on } \\
\text { decisions and organisational strate- } \\
\text { gies, management by way of aims, } \\
\text { physical \& mental strain due to one's } \\
\text { work, competition and tense interper- } \\
\text { sonal relationships, neglecting opin- } \\
\text { ions of executive staff, nepotism, lack } \\
\text { of rational criteria of awards and } \\
\text { promotion, lack of incentive pay } \\
\text { systems, unfair and biased judgement, } \\
\text { etc. }\end{array}$ \\
\hline $\begin{array}{c}\text { Categories } \\
\text { of organisa- } \\
\text { tional climate } \\
\text { (cont.) } \\
\end{array}$ & $\begin{array}{l}\text { Mechanistic organisation } \\
\text { (Dominant features of the climate } \\
\text { of bureaucracy according to the } \\
\text { author's research) }\end{array}$ & $\begin{array}{l}\text { Organic organisation } \\
\text { (Dominant features of the climate } \\
\text { of adhocracy according to the au- } \\
\text { thor's research) }\end{array}$ \\
\hline Responsibility & $\begin{array}{l}\text { poor organisation of team work, } \\
\text { subordinates have a sense of obliga- } \\
\text { tion towards the organisation, but } \\
\text { do their work out of necessity; } \\
\text { workers loyalty has its price, they } \\
\text { would change the company, but } \\
\text { keep doing their work feeling un- } \\
\text { derpaid due to the fear of losing it, } \\
\text { they prefer situations in which they } \\
\text { have an opportunity to make deci- } \\
\text { sions in an autonomous way and be } \\
\text { responsible for them, etc. }\end{array}$ & $\begin{array}{l}\text { poor organisation of team work, } \\
\text { subordinates have a sense of obliga- } \\
\text { tion towards the organisation, but do } \\
\text { their work out of necessity; they are } \\
\text { not entirely loyal towards their organ- } \\
\text { isation, consider themselves responsi- } \\
\text { ble for it, but feel threatened and } \\
\text { underappreciated, they are ready and } \\
\text { inclined to bear responsibility in } \\
\text { return for decision-making rights, etc. }\end{array}$ \\
\hline Risk & $\begin{array}{l}\text { need of professional stabilisation, } \\
\text { recognition of superiors \& man- } \\
\text { agement's competence, poor organ- } \\
\text { isation of work; they would choose } \\
\text { a job in which they would get a } \\
\text { bigger salary, without the need for } \\
\text { improving one's skills, etc. }\end{array}$ & $\begin{array}{l}\text { the feeling of threat, attitudes of } \\
\text { rivalry, unfriendly interpersonal } \\
\text { relationships, stress caused by sudden } \\
\text { change and unexpected reversal of } \\
\text { situation, etc. }\end{array}$ \\
\hline
\end{tabular}




\begin{tabular}{||l|l|l||}
\hline Warmth & $\begin{array}{l}\text { distanced interpersonal relation- } \\
\text { ships, fear of the lack of support } \\
\text { from one's superiors etc. }\end{array}$ & $\begin{array}{l}\text { relations based on rivalry, lack of } \\
\text { decision-making influence, sense of } \\
\text { obligation and excessive workload } \\
\text { etc. }\end{array}$ \\
\hline Support & $\begin{array}{l}\text { lack of involvement in subordi- } \\
\text { nates' matters, centralisation, limit- } \\
\text { ing one's influence on organisa- } \\
\text { tional processes etc. }\end{array}$ & $\begin{array}{l}\text { lack of involvement in subordinates' } \\
\text { matters, centralisation, limiting one's } \\
\text { influence on organisational processes, } \\
\text { trainings and development of one's } \\
\text { professional competence etc. }\end{array}$ \\
\hline Standards & $\begin{array}{l}\text { norms are: certainty of employ- } \\
\text { ment, pessimism, trained helpless- } \\
\text { ness, attachment \& priority for } \\
\text { comfortable working conditions, } \\
\text { apathy and reluctance to raise quali- } \\
\text { fications and develop professional- } \\
\text { ly, truths told about the significance } \\
\text { of the performed roles etc. }\end{array}$ & $\begin{array}{l}\text { norms are: the feeling of helplessness, } \\
\text { lack of influence on the manage- } \\
\text { ment's decisions \& organisational } \\
\text { strategy, low self-esteem in the con- } \\
\text { text of being evaluated by one's } \\
\text { supervisors, necessity of doing one's } \\
\text { work, feeling the lack of support etc. }\end{array}$ \\
\hline Conflict & $\begin{array}{l}\text { superiors solve conflicts effectively, } \\
\text { exert influence with the use of } \\
\text { formal authority; in a hierarchical } \\
\text { organisation, the factor which } \\
\text { supports modelling behaviours is } \\
\text { the formalisation of processes, etc. }\end{array}$ & $\begin{array}{l}\text { superiors solve conflicts effectively, } \\
\text { exert influence by way of directive } \\
\text { management style, using traditional } \\
\text { methods of reinforcement, award \& } \\
\text { punishment; fear of losing one's job } \\
\text { determines the type of relation, etc. }\end{array}$ \\
\hline $\begin{array}{l}\text { the work itself gives satisfaction, } \\
\text { but it may be done for another } \\
\text { employer, if he guarantees fairly } \\
\text { comfortable and very financially } \\
\text { attractive conditions etc. }\end{array}$ & $\begin{array}{l}\text { the work done gives satisfaction, the } \\
\text { more so if it gives employees an } \\
\text { opportunity to meet existential, social } \\
\text { and dictated by ambition needs. }\end{array}$ \\
\hline
\end{tabular}

Obtained results seem to prove the proposed research hypotheses, since by way of theoretical and empirical analysis no grounds for rejecting them have been discerned. Therefore, one ought to accept as true, in a spirit of Popper's disproof of hypotheses, theses proving that:

- $\quad$ organisational culture manifested in organisational climate is in fact visible in characteristic attitudes of organisation members, expressed in the form of specific views and beliefs (element of knowledge), feelings (emotional element) and behaviours (behavioural element),

- in an area of attitudes towards organisational climate, differences in beliefs among the members of adhocracy and bureaucracy will appear,

which have been attempted to prove in the course of the presented findings and substantiated in the attached tabular juxtaposition.

\section{CONCLUSIONS}

As a result of the carried out discourse along with its findings, it seems completely justified to arrive at some final conclusions, among which the following have been recognised as entitled to be formulated:

- thesis one - organisational culture is expressed in specific attitudes of organisation members, which consist of three dimensions: knowledge, feelings and behaviours, 
- thesis two - characterisation of attitudes is created by the influence of social mechanisms and the process of learning, which condition the forming of organisational culture,

- thesis three - climate prevailing in the organisation, which displays the qualities of culture present in the organisation, is expressed in attitudes,

- thesis four - organisation climate of state enterprises is different from the one of market enterprises, since the dissonance in this aspect is evident in the attitudes of their employees,

- thesis five - regardless of the type of organisation and the relevant culture, organisational climate of Polish companies both state and market does not express the atmosphere of joint participation, commitment as well as co-decision. An average market organisation ranked among achievement culture, in which innovativeness, creativity and ambition are so to speak dogmatically supported, and development in realities of Polish economy takes a degenerated form, which resembles only this type of culture, because it is also characterised by the atmosphere of rivalry. One tends to forget about the ethnocentric principle of objective and fair judgement, which in the face of the whole inconvenience of rules for working in achievement culture (the rat race syndrome), is characterised by simply stringent criteria of awarding and promoting. Protectionism excludes the evolutionary process of improving organisational mechanisms and processes, being the greatest enemy of progress based on progressive organisational culture. Civil service and state enterprises, ranked among role culture, in which work is controlled by means of procedures and regulations, and tasks as well as organisational aims are more significant than the person who fulfils them. $\mathrm{Au}-$ thority is divided here between the leader and bureaucratic structure, roles are clearly defined, and hierarchy, position and status acquire major significance. Hence, one may find it strange that in formalised, legal and rational conditions, members of this type of culture discern nepotism and organisational disorder,

- thesis six - the dominant method of development and improvement in organisational climate, and at the same time organisational culture, is investing in the progression of knowledge and intellectual capital of the organisation, which create favourable conditions to develop the right attitudes: innovativeness, creativity and resourcefulness.

A factor which diversifies organisations into various forms is the structure of their environment, and above all its stability, unpredictability and changeability ${ }^{17}$. Behaviours of the organisation in steady and predictable surroundings are characterised by monotony and specialisation in doing routine activities in conditions of strict hierarchy of authorities, and also explicitly and clearly determined job descriptions ${ }^{18}$. A model of a machine with specialised functions and high operating effectiveness becomes a metaphorical illustration of the characteristics of structure and activity of the bureaucratic type of organisation ${ }^{19}$.

\footnotetext{
${ }^{17}$ K. Mrozowicz, Klastry przedsiębiorczości w świetle teorii organizacji, Nauka i Gospodarka, 2010/1, UE w Krakowie, Kraków 2010, p. 67.

${ }^{18}$ M.J. Hatch, Teoria organizacji, PWN, Warszawa 2002, p. 88.

${ }^{19}$ G. Morgan, op. cit., pp. 17-33.
} 
In turbulent surroundings, subject to frequent and quick changes, which makes it for the organisation a source of permanent uncertainty, they need much higher expression and dynamics of action, elasticity of boundaries, structures, mechanisms and processes, also including adaptive skills, manifested in the improvement in the quality of social potential, as well as in the adaptation of technological processes in accordance with the demands of the environment ${ }^{20}$. Allegorical models of living organisms, which similarly to living beings flexibly adapt to the changing circumstances and environmental conditions, accommodating to situations and adjusting their build and functions to the possibilities existing in the environment, are applied to adhocracy ${ }^{21}$. Elasticity corresponding to organic organisational forms (adhocracy, matrix, network, cluster etc.) increases creativity, innovativeness, adaptive and didactic abilities, and development of enterprise culture, based on multilateral, diverse and interdisciplinary management methods ${ }^{22}$. Logic and profitability of mechanisation, specialisation, routine as well as standardisation of knowledge, beliefs and behaviours may turn out more effective in monothematic, stable and hierarchical conditions. Tom Burns and George Stalker proved in a convincing way that dissimilar conditions of environment force the organisation to use distinct organisational activities, and the most effective ones from them are conditioned each time by the complexity and changeability of environment ${ }^{23}$.

Finally, it is worth adding that the role of organisation does not restrict itself only to reactions to limitations and conditions, which the environment imposes upon its actions and the behaviour of their members, but includes active and innovative activity of its social potential, management in particular, in using appropriate management methods in order to facilitate its mechanisms adjusting it to unstable domination of environment.

\section{REFERENCES}

[1] Armstrong M.: Zarządzanie zasobami ludzkimi, Oficyna Ekonomiczna, Kraków 2005.

[2] Burns T., Stalker G.M.: The management of innovation, Tavistock, London 1961.

[3] Cameron K.S., Quinn R.E.: Kultura organizacyjna - diagnoza i zmiana. Model wartości konkurujących, Oficyna Ekonomiczna, Kraków 2003.

[4] French W.L., Kast F.E., Rosenzweig J.E.: Understanding Human Behaviour in Organizations, Harper \& Row, New York 1985.

[5] Furnham A., Gunter B.: Corporate Assessment, Routledge, London 1993.

[6] Handy C.: Understanding Organizations, Penguin, Harmondsworth 1981.

[7] Harrison R.: Understanding your organizations character, Harvard Business Review, 1972, 5, pp.119-128.

[8] Hatch M.J.: Teoria organizacji, PWN, Warszawa 2002.

[9] Kłak B., Kłak D.: Kapitał intelektualny w kształtowaniu wartości przedsiębiorstwa, w: Galata S. (red.), Uwarunkowania strategii zarządzania nowoczesnymi organizacjami, Wydawnictwo Naukowo - Dydaktyczne PWSZ w Jarosławiu, Jarosław 2008.

[10] [10] Kłak D.: Organizational dimension of management of human capital selection process, Pragmata tes Oikonomias - VIII, Wydawnictwo Akademii im. Jana Długosza w Częstochowie, Częstochowa 2014.

\footnotetext{
${ }^{20}$ M.J. Hatch, op. cit., p. 88.

${ }^{21}$ G. Morgan, op. cit., pp. 41-79.

${ }^{22}$ K. Mrozowicz, op. cit..

${ }^{23}$ T. Burns, G.M. Stalker, The management of innovation, Tavistock, London 1961.
} 
[11] Litwin G.H., Stringer R.A.: Motivation and Organizational Climate, Harvard University Press, Boston 1968.

[12] Morgan G.: Obrazy organizacji, PWN, Warszawa 2005.

[13] Mrozowicz K.: Klastry przedsiębiorczości w świetle teorii organizacji, Nauka i Gospodarka, 2010/1, UE w Krakowie, Kraków 2010.

[14] Schein E.H.: Organization Culture and Leadership, Jossey-Bass, New York 1985.

[15] Williams A., Dobson P., Walters M.: Changing Culture: New organizational approaches, IPA, London 1989.

\section{KLIMAT ORGANIZACYJNY JAKO OBRAZ KULTURY ORGANIZACJI (W ŚWIETLE BADAŃ ORGANIZACJI POLSKICH)}

Artykuł jest próbą naukowej reprezentacji specyfiki kultury organizacyjnej polskich firm, a także różnic w zakresie kształtowania się atrybutów kultur organizacji państwowych oraz rynkowych, przy zastosowaniu empirycznej oceny postaw ich członków w stosunku do panującego w nich klimatu organizacyjnego.

Klimat organizacyjny rozumiany jest tutaj jako wizualizacja (unaocznienie, materializacja) ,podświadomych”, głębokich i ukrytych przed otoczeniem organizacji, a także w pewnym sensie przed nią samą wartości, norm i artefaktów. Zjawisko klimatu organizacyjnego jest o tyle interesujące $\mathrm{z}$ naukowego punktu widzenia, że może ono ze względu na swój wolicjonalny (członkowie organizacji mają możność), kongwistyczny (członkowie mają zdolność intelektualną), emocjonalny (członkowie są skłonni) i psychomotoryczny (członkowie posiadają kompetencje techniczne) charakter zostać poddane empirycznej weryfikacji w postawach pracowniczych. Jest też stosunkowo łatwo osiągalnym źródłem danych, co podnosi jego wartość praktyczną i obniża koszty badań. Klimat organizacyjny stanowi - w przyjętej przez autorów artykułu konwencji analitycznej - logiczną, intuicyjną, uogólnioną i zgeneralizowaną formę postrzegania oraz wyrażania przez społeczność (jednostkę, grupę, zespół) organizacji - w postaci odczuć, opinii oraz zachowań jej uczestników - cechującej ją kultury.

Celem badań uczyniono przeto analizę diakrytyczną klimatu organizacyjnego biurokracji i adhokracji (klimat organizacyjny w uznaniu autorów jest syntetycznym oraz integralnym odpowiednikiem kultury organizacji, traktowanym w ramach przyjętego paradygmatu synonimicznie), kształtujących się w polskich organizacjach.

Słowa kluczowe: kultura organizacyjna, kapitał ludzki, klimat organizacyjny

\section{DOI: 10.7862/rz.2014.mmr.34}

Tekst złożono w redakcji: wrzesień 2014

Przyjęto do druku: wrzesień 2014 